\title{
RELEVANSI NILAI INFORMASI AKUNTANSI TERHADAP HARGA SAHAM YANG DIMODERASI KONSERVATISME AKUNTANSI
}

\author{
Margareta Chaslim * \\ Carmel Meiden \\ Program Studi Akuntansi, Institut Bisnis dan Informatika Kwik Kian Gie, \\ Jl. Yos Sudarso Kav. 87, Jakarta 14350
}

\begin{abstract}
An information content of the published financial statements is said to have value relevance if it is able to revise investor beliefs as reflected in market reaction through stock price changes. Nevertheless, many issues suggest that the value relevance of accounting information has declined, mainly due to the increasing practices of conservatism. This research purpose is to know and prove the value relevance of accounting information and the impact of conservatism on the value relevance of the manufacturing firms listing in the Indonesian Stock Exchange in the period of 2013-2016. The sample used amounted to 320 observations consisting of 80 companies each year. Based on data analysis techniques with multiple linear regression analysis, it was found that accounting information proved to have value relevance to the stock price, as well as accounting conservatism have a different effect on each accounting information.
\end{abstract}

Keywords: Value relevance, accounting information, stock price, conservatism

\begin{abstract}
Abstrak
Suatu kandungan informasi dari laporan keuangan yang dipublikasikan dikatakan memiliki relevansi nilai apabila mampu merevisi keyakinan investor yang tercermin dari reaksi pasar lewat perubahan harga saham. Namun, banyak isu yang menyebutkan bahwa belakangan ini relevansi nilai informasi akuntansi semakin menurun, terutama disebabkan oleh praktik konservatisme yang semakin meningkat. Penelitian ini bertujuan untuk mengetahui dan membuktikan keberadaan relevansi nilai informasi akuntansi dan pengaruh penerapan konservatisme akuntansi terhadap relevansi nilai pada perusahaan manufaktur yang terdaftar di BEI periode 2013-2016. Sampel yang digunakan berjumlah 320 observasi yang terdiri dari 80 perusahaan setiap tahun. Berdasarkan teknik analisis data dengan analisis regresi linier ganda, ditemukan bahwa informasi akuntansi terbukti memiliki relevansi nilai terhadap harga saham, serta konservatisme akuntansi memiliki pengaruh yang berbeda pada setiap informasi akuntansi.
\end{abstract}

Kata kunci: Relevansi nilai, informasi akuntansi, harga saham, konservatisme

\section{Pendahuluan}

$\mathrm{K}$

andungan informasi akuntansi menjadi suatu bahan pertimbangan penting yang senantiasa digunakan oleh investor dalam pengambilan keputusan investasi, khususnya di pasar saham.
Penyajian informasi akuntansi yang relevan pada investor maupun pengguna laporan keuangan lainnya dapat membantu mereka dalam pengambilan keputusan (Mashayekhi et al., 2013). Suatu laporan keuangan memiliki kandungan informasi apabila publikasi laporan keuangan tersebut

\footnotetext{
* Alamat kini:Institut Bisnis dan Informatika Kwik Kian Gie, Jln Yos Sudarso Kav. 87 Sunter , Jakarta 14350 Penulis untuk Korespondensi: Telp. (021) 65307062 Ext. 808. E-mail: carmel.meiden@kwikkiangie.ac.id
} 
menyebabkan timbulnya reaksi pasar, yaitu berupa reaksi investor untuk mengevaluasi kembali strategi investasinya yang selanjutnya akan berdampak pada harga saham (Nyabundi, 2013).

Namun, dalam kenyataannya masih ditemukan sejumlah kasus yang menunjukkan bahwa relevansi nilai dari kandungan informasi akuntansi ini belum sepenuhnya dapat diwujudkan lewat laporan keuangan yang dipublikasikan, salah satunya adalah yang dialami oleh perusahaan otomotif asal Berlin, yaitu Volkswagen (VW) yang menunjukkan walaupun laba operasionalnya naik dari angka US\$ 3,3 miliar pada kuartal I 2015 menjadi US\$ 3,8 miliar pada kuartal I 2016, tetapi pasca publikasi laporan keuangan harga saham VW turun $3,8 \%$ menjadi $€$ 132,80 (Kontan, 2016). Senada dengan kejadian yang terjadi di Bursa Saham Frankfurt, kasus yang dialami oleh emiten PT. Gudang Garam Tbk (GGRM) yang terjadi di Bursa Efek Indonesia, menunjukkan bahwa harga sahamnya menurun sebesar $3,18 \%$ pada pertengahan April 2017 padahal laporan keuangan tahunan 2016 yang dipublikasikan 10 April 2017 mengalami peningkatan pada laba bersihnya sebesar $3,41 \%$.

Berdasarkan fenomena tersebut, informasi laba merupakan unsur yang sering dikaitkan dengan relevansi nilai. Beberapa peneliti terdahulu secara konsisten menunjukkan bahwa laba memiliki relevansi nilai dengan harga saham karena secara statistik memiliki hubungan positif dan signifikan terhadap harga saham (Karunarathne \& Rajapakse, 2010; Viandita et al., 2013), namun tidak sejalan dengan penelitian (Almilia \& Sulistyowati, 2007; Sugiarti \& Suyanto, 2007). Selain informasi laba, nilai buku ekuitas juga sering dikaitkan dengan penelitian relevansi nilai. Bahkan, nilai buku ekuitas memiliki relevansi nilai yang lebih tinggi terhadap harga saham dibandingkan dengan nilai laba, terutama saat perusahaan mengalami tingkat laba yang negatif (Collins et al., 1997; Kwon, 2009). Beberapa peneliti terdahulu secara konsisten menunjukkan bahwa nilai buku ekuitas memiliki relevansi nilai dengan harga saham karena secara statistik memiliki hubungan positif dan signifikan (Adibah et al., 2009; Karunarathne \& Rajapakse, 2010), namun tidak sejalan dengan penelitian (Stella, 2009; Omokhudu \& Ibadin, 2015).

Penelitian relevansi nilai juga sering dikaitkan dengan arus kas operasi. Bahkan beberapa peneliti menganggap bahwa unsur arus kas operasi lebih memiliki relevansi nilai dibanding nilai laba (Black, 1998; Kwon, 2009). Arus kas operasi memiliki relevansi nilai apabila secara statistik memiliki hubungan positif dan signifikan terhadap harga saham (Omokhudu \& Ibadin, 2015), namun tidak sejalan dengan penelitian (Mutia, 2012). Selain informasi mengenai arus kas operasi, nilai leverage juga sering digunakan sebagai bahan pertimbangan investor dalam pengambilan keputusan investasi, oleh karena itu nilai leverage ini dikatakan memiliki relevansi nilai (Dimitrov \& Jain, 2008). Nilai leverage yang diproksikan oleh debt to equity ratio memiliki relevansi nilai apabila secara statistik memiliki hubungan positif dan signifikan terhadap harga saham (Pebriana, 2014), namun bertentangan dengan hasil penelitian (Devi \& Badjra, 2014; Haghiri \& Haghiri, 2012).

Penelitian terdahulu secara konsisten mengungkapkan bahwa terjadi penurunan relevansi nilai informasi akuntansi dari waktu ke waktu (Lev \& Zarowin, 1999; Kousenidis et al., 2009). Penurunan relevansi nilai tidak hanya terjadi pada negara tertentu, tapi juga berdampak sampai ke ranah internasional (Hail, 2013). Fenomena ini juga berdampak di Indonesia melalui penelitian yang menemukan bahwa relevansi nilai informasi akuntansi di Indonesia juga mengalami penurunan dari waktu ke waktu (Pinasti, 2004; Widiastuti \& Meiden, 2012). Banyak yang mengklaim bahwa penurunan tingkat relevansi nilai informasi akuntansi disebabkan oleh meningkatnya praktik konservatisme akuntansi (Givoly \& Hayn, 2000; Karami \& Hajiazimi, 2013). Namun, terdapat sejumlah penelitian yang menyanggah hasil penelitian di atas dengan membuktikan bahwa turunnya relevansi nilai tidak berkaitan dengan penerapan prinsip 
konservatisme akuntansi (Balachandran \& Mohanram, 2005; Kousenidis et al., 2009). Dengan demikian, masih terdapat banyak perbedaan pendapat dan inkonsistensi hasil terkait peranan konservatisme akuntansi terhadap relevansi nilai informasi akuntansi.

Sektor industri manufaktur diprediksi menjadi pendongkrak pertumbuhan ekonomi nasional di tahun 2018 (Luciana, 2017). International Yearbook Industrial Statistic 2016 juga mencatat bahwa saat ini Indonesia berhasil meraih posisi ke-9 negara industri manufakur terbesar di dunia (Julianto, 2017). Lebih lanjut, pemilihan perusahaan manufaktur sebagai obyek penelitian dikarenakan sesuai dengan fakta yang telah dijelaskan, kasus yang melibatkan perusahaan manufaktur lebih banyak atau mendominasi jika dibandingkan dengan perusahaan lainnya.

Permasalahan dalam penelitian ini adalah apakah informasi akuntansi berupa laba, nilai buku ekuitas, leverage, dan arus kas operasi memiliki relevansi nilai terhadap harga saham, serta bagaimana pengaruh penerapan konservatisme akuntansi pada relevansi nilai informasi akuntansi. Tujuan penelitian ini adalah untuk membuktikan relevansi nilai dari informasi akuntansi terhadap harga saham dan pengaruh penerapan konservatisme akuntansi pada relevansi nilai informasi akuntansi.

\section{Kajian Pustaka}

\section{Teori Clean Surplus}

Scott (2015) menunjukkan bahwa nilai pasar perusahaan tersebut pada umumnya tercermin dari variabel-variabel fundamental yang terdapat dalam laporan laba rugi dan neraca. Dalam hubungan clean surplus, dikenal istilah net of capital contribution. Dimana nilai dari net of capital contribution merupakan selisih antara perubahan nilai aktiva/kewajiban yang selanjutnya tercermin dalam nilai laba bersih (net income) dikurangi dengan nilai dividen yang secara langsung berhubungan terhadap perubahan nilai laba ditahan dalam ekuitas (neraca).
Hubungan yang bersifat clean surplus ini mengindikasikan bahwa perubahan nilai aktiva/kewajiban (net income) mempunyai hubungan yang tidak langsung terhadap perubahan laba ditahan dalam ekuitas (neraca) karena berasal dari laporan laba rugi (Ohlson, 1995). Suatu informasi dikatakan relevan apabila informasi tersebut dapat digunakan oleh investor dalam memprediksi nilai pasar perusahaan. Nilai pasar perusahaan dapat dipahami sebagai gabungan antara nilai buku ekuitas yang mencerminkan nilai pasar saat ini dengan laba agregasi perusahaan yang diharapkan di masa yang akan datang yang nilainya dihitung berdasarkan present value of future accumulated net income (Ohlson, 1995). Dengan demikian, nilai buku ekuitas dan laba merupakan variabel dasar yang berpengaruh secara tidak langsung dalam menentukan nilai perusahaan.

\section{Signalling Theory}

Teori sinyal adalah teori yang menjelaskan bagaimana seharusnya sebuah perusahaan memberikan sinyal kepada pengguna laporan keuangan (Mashayekhi et al., 2013). Teori sinyal mengindikasikan bahwa pasar akan bereaksi dengan menunjukkan sebuah perbedaan klasifikasi atas informasi yang dipandang memberikan sinyal yang baik (good news) dan sinyal yang buruk (bad news). Suatu kandungan informasi akuntansi dikatakan memiliki relevansi nilai apabila informasi tersebut mampu memberikan sinyal yang baik kepada investor untuk merevisi keyakinannya yang selanjutnya tercermin lewat kenaikan harga saham.

\section{Agency Theory}

Teori keagenan didasari oleh adanya hubungan persetujuan antara dua pihak dimana salah satu pihak (agent) setuju untuk bertindak bagi pihak lainnya (principal). Hubungan ini berjalan dengan baik ketika agen mampu membuat keputusan yang sesuai dengan kehendak principal dan tidak akan berjalan baik ketika terjadi perbedaan kepentingan (Gitman \& Zutter, 2015). Suatu 
informasi akuntansi dikatakan memiliki relevansi nilai yang positif dan signifikan dalam meningkatkan nilai perusahaan, apabila informasi yang disampaikan oleh manajer yang bertindak sebagai agent selaras dengan tujuan yang diharapkan oleh pemegang saham yang bertindak sebagai principal yang selanjutnya dapat menurunkan konflik kepentingan dan biaya keagenan.

\section{Teori Pasar Efisien}

Pasar yang efisien dicirikan oleh seberapa cepat reaksi pasar saat suatu informasi baru dipublikasikan (Scott, 2015). Maka pasar efisien bentuk semi-strong adalah bentuk pasar efisien yang berkaitan langsung dengan penelitian relevansi nilai, karena semua informasi dalam laporan keuangan khususnya informasi akuntansi haruslah merupakan informasi yang tersedia di publik. Felix \& Rebecca (2015) menambahkan bahwa suatu pasar dikatakan efisien apabila nilai pasar mampu mencerminkan keyakinan dan estimasi investor.

\section{Relevansi Nilai}

Relevansi nilai (value relevance) mempunyai arti kemampuan menjelaskan (explanatory power) dari informasi akuntansi dalam kaitannya dengan nilai perusahaan. Suatu informasi akuntansi dikatakan relevan apabila informasi tersebut mampu menciptakan perbedaan di dalam pengambilan keputusan (Kieso et al., 2014). Model penilaian yang umum digunakan adalah model harga dan model return. Penelitian ini menggunakan model harga karena hubungan antara indikator laporan keuangan dan return lebih memperlihatkan sisi risiko bagi perusahaan serta tidak menunjukkan abnormal return bagi perusahaan (Sugiarti \& Suyanto, 2007). Relevansi nilai ditentukan dengan pengujian hubungan statistik antara informasi akuntansi dengan harga saham, jika hubungan statistik tersebut positif signifikan maka informasi tersebut dikatakan relevan (Barth et al., 2001; Mashayekhi et al., 2013). Jika informasi akuntansi bermanfaat dan digunakan oleh investor sebagai dasar pembuatan keputusan, maka reaksi investor tersebut akan tercermin pada perubahan volume atau harga saham (Scott, 2015).

\section{Laba}

Suwardjono (2014) menjelaskan bahwa laba akuntansi yang diumumkan melalui laporan keuangan merupakan sinyal dari sekumpulan informasi yang tersedia bagi pasar modal. Laba yang diproksikan dengan laba per saham (earning per share) merupakan suatu indikator untuk mengukur tingkat efisiensi manajemen, karena mengandung informasi yang berguna untuk memprediksi dividen dan harga saham di masa mendatang. (Schroeder et al., 2014:203). Sehingga laba dikatakan memiliki relevansi nilai dalam asosiasi yang positif dan signifikan terhadap harga saham (Nyabundi, 2013; Omokhudu \& Ibadin, 2015).

\section{Nilai Buku Ekuitas}

Nilai buku ekuitas dipandang sebagai proksi bahwa perusahaan akan dapat bertahan dan menghasilkan laba positif yang diharapkan dari hasil operasi normalnya di masa yang akan datang dan juga sebagai proksi bagi nilai penolakan terutama ketika perusahaan sedang mengalami kerugian (Collins et al., 1999). Dengan demikian nilai buku ekuitas sebagai informasi akuntansi yang merupakan unsur pembentuk nilai perusahaan yang tercermin pada harga pasar saham perusahaan. Sehingga nilai buku ekuitas dikatakan memiliki relevansi nilai terhadap harga saham dalam asosiasi yang positif dan signifikan (Hail, 2013; Lam et al., 2013).

\section{Leverage}

Nilai leverage mencerminkan kelangsungan hidup perusahaan yaitu kemampuan perusahaan untuk tetap going concern (Schroeder et al., 2014). Leverage yang diproksikan oleh DER menggambarkan kemampuan modal sendiri untuk memenuhi kewajiban dan mengantisipasi hutang. Nilai 
DER yang tinggi cenderung membuat manajer dalam perusahaan memilih metode akuntansi yang dapat meningkatkan laba saat ini dibandingkan dengan laba periode mendatang, yang selanjutnya meningkatkan harga saham. Sehingga DER dikatakan memiliki relevansi nilai terhadap harga saham dalam asosiasi yang positif dan signifikan (Pebriana, 2014).

\section{Arus Kas Operasi}

Informasi yang terdapat dalam laporan arus kas, khususnya arus kas operasi mengandung nilai akrual, sehingga merupakan prediktor yang baik dalam memprediksi arus kas masa depan (Watts \& Zimmerman, 1986). Semakin tinggi arus kas dari aktivitas operasi menunjukkan perusahaan tersebut mampu beroperasi secara menguntungkan serta mengurangi ketidakpastian dalam hal pembayaran dividen (Zakic et al., 2012). Sehingga arus kas operasi memiliki relevansi nilai harga saham dalam asosiasi yang positif dan signifikan (Hail, 2013; Omokhudu \& Ibadin, 2015).

\section{Konservatisme Akuntansi}

Konservatisme merupakan suatu prinsip kehati-hatian dalam pelaporan keuangan, yang mensyaratkan tingkat verifikasi yang lebih tinggi pada saat mengakui laba dibandingkan saat mengakui rugi (Watts, 2003). Hingga saat ini masih terdapat sejumlah perdebatan mengenai kebermanfaatan dari penerapan praktik akuntansi konservatif. Pihak yang mendukung praktik ini menyatakan bahwa praktik ini diyakini menguntungkan karena dapat mengurangi perilaku manajer yang oportunis (Watts, 2003), selain itu juga praktik ini bermanfaat dari sisi agensi karena dapat mengurangi terjadinya konflik keagenan atau tuntutan hukum (Mayangsari, 2004), sehingga dapat mengurangi biaya keagenan. Sedangkan pihak yang menentang praktik ini beranggapan bahwa konservatisme menjadi penyebab menurunnya relevansi nilai informasi akuntansi (Karami \& Hajiazimi, 2013) dan cenderung menyebabkan kualitas laba yang dilaporkan menjadi rendah (Penman \& Zhang, 2002).

Perusahaan yang menerapkan praktik konservatisme, cenderung memiliki tendensi untuk menunda pengakuan pendapatan sampai benar-benar ada bukti dan dikatakan terjadi, namun mengakui biaya sesegera mungkin. Akibatnya, informasi laba yang disajikan dikatakan mengandung bias ke bawah karena terjadi pengakuan yang asimteris antara pendapatan dan biaya. Informasi laba yang bias ke bawah selanjutnya akan direspon secara negatif oleh investor, hal ini tampak pada investor yang tidak merevisi keyakinannya dan ditunjukkan oleh permintaan akan saham yang semakin menurun dan berujung pada turunnya harga saham. Sehingga konservatisme memperlemah relevansi nilai laba terhadap harga saham (Darsono, 2012). Selain itu, perusahaan yang menerapkan prinsip konservatif, cenderung melaporkan laba pada tingkat yang negatif. Perusahaan yang memiliki nilai laba yang negatif cenderung tidak mampu untuk menjalankan aktivitas operasinya dengan lancar termasuk melunasi kewajibannya dalam hal membagi dividen, karena tidak tersedianya arus kas yang cukup. Hal ini dapat menurunkan kepercayaan investor yang selanjutnya membuat nilai pasar perusahaan yaitu harga saham menjadi turun.

Pelaporan laba yang bias dan bernilai negatif tidak mampu memprediksi pendapatan masa mendatang, akibatnya investor beralih pada peranan nilai buku ekuitas sebagai proksi nilai penolakan (rejecting value). Pada saat perusahaan mengantisipasi pelaporan keuntungan yang terjadi dengan cenderung melaporkan laba yang negatif, investor akan beralih pada kemampuan nilai buku ekuitas, hal ini sesuai dengan penemuan (Darsono, 2012) yang berhasil membuktikan bahwa konservatisme memperkuat relevansi nilai buku ekuitas terhadap harga saham. Hal senada dialami oleh perusahaan dengan tingkat leverage yang tinggi yang cenderung lebih diawasi dan menerapkan prinsip kehati-hatian (Lo, dalam Dewi \& Suryanawa, 2014). Tingginya 
tingkat pengawasan ini diharapkan dapat mengurangi konflik yang umumnya terjadi serta dapat meningkatkan keterandalan kualitas informasi laporan keuangan dalam pengambilan keputusan investasi, yang selanjutnya berdampak pada nilai perusahaan. Sehingga praktik konservatisme cenderung memperkuat relevansi nilai leverage terhadap harga saham.

Berdasarkan teori-teori tersebut, berikut rumusan hipotesis yang kami kembangkan: H1: Informasi akuntansi (laba, nilai buku, leverage, arus kas operasi) masih memiliki relevansi nilai terhadap harga saham

H2: Konservatisme akuntansi memperlemah relevansi nilai informasi akuntansi (laba, arus kas operasi) terhadap harga saham

H3: Konservatisme akuntansi memperkuat relevansi nilai informasi akuntansi (nilai buku ekuitas, leverage) terhadap harga saham

\section{Metode Penelitian}

\section{Obyek Penelitian}

Obyek penelitian yang digunakan dalam penelitian ini adalah perusahaan yang termasuk dalam industri manufaktur yang telah go public dan menerbitkan laporan keuangan tahunan pada periode 2013-2016 yang terdaftar di Bursa Efek Indonesia (BEI) dan dilihat dari Indonesia Capital Market Directory (ICMD), www.idx.co.id, serta www.sahamok.com.

\section{Variabel Penelitian}

\section{Harga Saham}

Variabel dependen dalam penelitian ini adalah harga saham penutupan (closing price) pada tanggal publikasi laporan keuangan (Darsono, 2012; Yendrawati \& Pratiwi, 2014).

\section{Laba}

Variabel laba yang diukur dengan laba per saham (earnings per share) dihitung dengan membagi keuntungan yang tersedia untuk pemegang saham biasa dengan jumlah saham biasa yang beredar (Gitman \& Zutter, 2015:87; Schroeder et al., 2014).

$E P S=\frac{\text { tarnings avalleble for commun stockhold ors }}{\text { Number of sharos of commun stocks outstanding }}$

\section{Nilai Buku Ekuitas}

Nilai buku ekuitas yang diukur dengan book value per share menunjukkan nilai aktiva bersih (net assets) yang dimiliki oleh pemegang saham untuk setiap satu lembar saham. Nilai aktiva bersih ini menunjukkan total ekuitas yang dimiliki pemegang saham (Kieso et al., 2011).

BVPS $=\frac{\text { Totel Stockholder's Equaty }}{\text { Number of shares of vomuvun stocks outstanding }}$

\section{Leverage}

Variabel leverage diukur dengan menggunakan debt to equity ratio yang menunjukkan perbandingan dari total hutang, termasuk hutang jangka panjang dengan total ekuitas pemilik (Devi \& Badjra, 2014).

$$
D E K=\frac{\text { Total debt }}{\text { Total Stockholder's Equity }}
$$

\section{Arus Kas Operasi}

Arus kas operasi per lembar saham menunjukkan hubungan antara kas yang dihasilkan dari kegiatan operasi dengan jumlah saham biasa yang beredar (Karunarathne \& Rajapakse, 2010).

$$
\text { UCFS }=\frac{\text { Not Cash Flows from Operating Activities }}{\text { IVumber of Shares of cummun Stock outstonding }}
$$

\section{Konservatisme Akuntansi}

Konservatisme dalam penelitian ini diproksikan dengan ukuran akrual seperti pada penelitian Pratanda \& Kusmuriyanto (2014) yang diadaptasi dari penelitian Givoly \& Hayn (2002). Apabila $\mathrm{C}_{\mathrm{it}}<0$, artinya konservatif, sedangkan $\mathrm{C}_{\mathrm{it}}>0$ artinya non konservatif.

$\mathrm{C}_{\mathrm{it}}=\mathrm{NI}_{\mathrm{it}}-\mathrm{CF}_{\text {it }}$ 
Keterangan :

$\mathrm{C}_{\mathrm{it}}=$ tingkat konservatisme

$\mathrm{NI}_{\mathrm{it}}$ = laba bersih sebelum extraordinary item ditambah depresiasi dan amortisasi

$\mathrm{CF}_{\text {it }} \quad=$ arus kas dari kegiatan operasional

\section{Teknik Pengambilan Sampel}

Teknik pengambilan sampel yang akan digunakan dalam penelitian ini adalah non-probabilistic sampling, yaitu metode purposive sampling tipe judgement sampling, di mana sampel yang disajikan obyek penelitian ditentukan berdasarkan kriteria tertentu, antara lain:

1. Perusahaan selalu terdaftar di Bursa Efek Indonesia pada periode 2013-2016 dan tidak mengalami delisting selama periode penelitian.

2. Data laporan keuangan selama periode 2013-2016 tersedia secara lengkap.

3. Perusahaan harus mempunyai laporan keuangan yang berakhir pada tanggal 31 Desember (periode akuntansi adalah tahun takwim). Hal ini dimaksudkan untuk menghindari adanya bias karena perbedaan periode laporan keuangan serta meningkatkan komparabilitas.

4. Perusahaan menyajikan laporan keuangan dalam mata uang Rupiah.

5. Perusahaan tidak melakukan Initial Public Offering (IPO) selama periode peneitian.
6. Perusahaan tidak mengalami peristiwa khusus selama periode penelitian seperti stock split, merger dan akuisisi, dan perpindahan ke sektor lain selain industri manufaktur.

\section{Teknik Analisis Data}

\section{Uji Fixed Effect: Least Square Dummy Variable Approach}

Pengujian ini diperlukan untuk menguji kesamaan koefisien kemiringan atau titik potong, hal ini dilakukan untuk memastikan apakah pooling data (penggabungan data cross section dan time series) dapat dilakukan. Agar dapat dipooling, persamaan regresi untuk setiap tahun haruslah identic atau disebut regresi coincident. Untuk mengujinya, peneliti menggunakan teknik dummy variable dengan nilai "1" untuk masing-masing tahun. Sebagai contoh dalam penelitian ini menggunakan data 4 tahun dari tahun 20132016, sehingga dummy 1 yaitu tahun 2013, dummy 2 yaitu tahun 2014, dan dummy 3 yaitu tahun 2015 dengan penjelasan sebagai berikut:

DT1: variabel dummy $(1=$ tahun $2013,0=$ selain tahun 2013)

DT2 : variabel dummy $(1=$ tahun $2014,0=$ selain tahun 2014)

DT3 : variabel dummy $(1=$ tahun $2015,0=$ selain tahun 2015)

\section{Analisis Regresi Ganda}

Analisis regresi ganda dilakukan dengan bantuan SPSS 20.0. Berikut ini adalah price regression model yang digunakan dalam penelitian ini:

\section{Model I:}

$\mathrm{CP}_{\mathrm{i}, \mathrm{t}}=\beta_{0}+\beta_{1} \mathrm{EPS}_{\mathrm{i}, \mathrm{t}}+\beta_{2} \mathrm{BVPS}_{\mathrm{i}, \mathrm{t}}+\beta_{3} \mathrm{DER}_{\mathrm{i}, \mathrm{t}}+\beta_{4} \mathrm{OCFS}_{\mathrm{i}, \mathrm{t}}+\mathrm{i}, \mathrm{t}$

Model II:

$\mathrm{CP}_{\mathrm{i}, \mathrm{t}}={ }_{0}+{ }_{1} \mathrm{EPS}_{\mathrm{i}, \mathrm{t}}+{ }_{2} \mathrm{BVPS}_{\mathrm{i}, \mathrm{t}}+{ }_{3} \mathrm{DER}_{\mathrm{i}, \mathrm{t}}+{ }_{4} \mathrm{OCFS}_{\mathrm{i}, \mathrm{t}}+{ }_{5} \mathrm{C}_{\mathrm{i}, \mathrm{t}} \mathrm{EPS}_{\mathrm{i}, \mathrm{t}}$

$+{ }_{6} \mathrm{C}_{\mathrm{i}, \mathrm{t}, \mathrm{BVPS}} \mathrm{BV}_{\mathrm{i}, \mathrm{t}}+{ }_{7} \mathrm{C}_{\mathrm{i}, \mathrm{t}} \cdot \mathrm{DER}_{\mathrm{i}, \mathrm{t}}+{ }_{8} \mathrm{C}_{\mathrm{i}, \mathrm{t}} \cdot \mathrm{OCFS}_{\mathrm{i}, \mathrm{t}}+{ }_{\mathrm{i}, \mathrm{t}}$

Keterangan :

$\mathrm{CP}_{\mathrm{i}, \mathrm{t}}$

$\mathrm{EPS}_{\mathrm{i}, \mathrm{t}}$

BVPS $_{\mathrm{i}, \mathrm{t}}$

$\mathrm{DER}_{\mathrm{i}, \mathrm{t}}$

OCFS $_{i, t}$

$\mathrm{C}_{\mathrm{i}, \mathrm{t}}$
: Closing Price perusahaan i pada periode $\mathrm{t}$

: Laba per lembar saham perusahaan perusahaan i pada periode $t$

: Nilai buku ekuitas per lembar saham perusahaan i pada akhir tahun $\mathrm{t}$

: debt to equity ratio perusahaan i pada periode $\mathrm{t}$

: arus kas operasi per lembar saham perusahaan i pada periode $\mathrm{t}$

: indeks konservatisme (Accrual) 


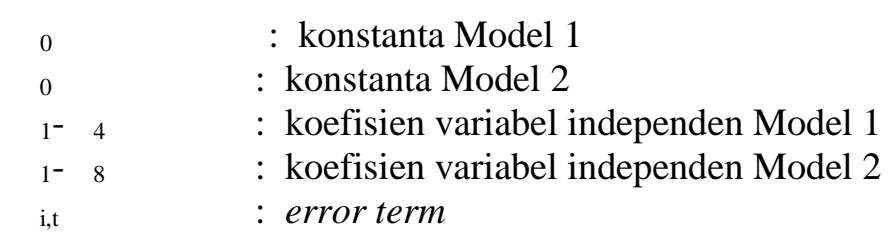

\section{Hasil Penelitian Dan Pembahasan}

\section{Hasil Penelitian}

\section{Uji Fixed Effect: Least Square Dummy Variable Approach}

Berdasarkan hasil uji pooling di Lampiran 2, dapat dilihat bahwa pooling data dapat dilakukan selama periode 2013-2016 untuk model regresi tanpa moderasi dan dengan moderasi konservatisme akuntansi. Hal ini ditunjukkan oleh nilai seluruh variabel dummy memiliki nilai signifikansi di atas 0,05 yang berarti terdapat kesamaan koefisien kemiringan dan titik potong pada regresi tersebut.

\section{Uji Asumsi Klasik}

Berdasarkan hasil uji asumsi klasik di Lampiran 2, hasil pengujian normalitas dengan One-Sample Kolmogorov-Smirnov test pada variabel dependen tanpa transformasi menunjukkan nilai asymp. Sig.(2-tailed) 0,000 di bawah 0,05 , hal ini menunjukkan nilai residual tidak berdistribusi normal. Peneliti selanjutnya melakukan transformasi dalam bentuk logaritma natural pada variabel dependen agar data berdistribusi normal. Hasil pengujian normalitas tanpa maupun dengan moderasi setelah ditransformasi menunjukkan nilai asymp. Sig.(2-tailed) 0,436 dan 0,484, lebih besar dari 0,05. Maka data residual berdistribusi normal. Pengujian multikolinearitas untuk model regresi tanpa moderasi menunjukkan nilai TOL $\searrow 0,1$ dan $\mathrm{VIF}<10$. Sedangkan model regresi dengan moderasi memperlihatkan nilai $\mathrm{TOL}<0,1$ dan VIF> 10 untuk Cit_EPS dan Cit_BVPS. Namun menurut (Disatnik \& Sivan, 2016) multikolinieritas hanya sebatas masalah pengukuran interval, sehingga hal tersebut tidak mempengaruhi validitas hasil dan tetap layak diinterpretasikan. Pengujian heteros- kedastisitas model regresi dengan dan tanpa moderasi dilakukan dengan uji Park, menunjukkan nilai signifikansi seluruh variabel independen berada di atas 0,05, maka tidak terjadi heteroskedastisitas pada kedua model. Pengujian autokorelasi untuk model regresi tanpa moderasi dilakukan dengan uji DurbinWatson dengan nilai dw 2,001 berada pada kisaran $\mathrm{du}<\mathrm{d}<4$-du sehingga tidak terjadi autokorelasi. Sedangkan pengujian autokorelasi untuk model regresi dengan moderasi dilakukan dengan uji run-test dengan nilai probabilitas 0,057 di atas tingkat kepercayaan $5 \%$, maka dapat disimpulkan tidak terjadi autokorelasi untuk kedua model yang diujikan.

\section{Uji Signifikansi Simultan (Uji F)}

Hasil pengujian pada semua model regresi yang diujikan, baik model regresi dengan dan tanpa konservatisme akuntansi, diperoleh tingkat signifikansi sebesar 0,000 seperti yang ditunjukkan dalam Lampiran 2 . Nilai ini berada di bawah tingkat kepercayaan yang digunakan yaitu 0,05 , sehingga dapat disimpulkan bahwa semua variabel yang diujikan serta interaksinya dengan konservatisme akuntansi, yaitu nilai laba per saham (EPS), nilai buku ekuitas per lembar saham (BVPS), nilai hutang dibagi total ekuitas (DER), dan nilai arus kas operasi per jumlah saham beredar (OCFS) serta interaksinya dengan konservatisme akuntansi (Cit_EPS, Cit_BVPS, Cit_DER, dan Cit_OCFS) secara bersama-sama berpengaruh signifikan terhadap harga saham.

\section{Uji Signifikansi Parameter Individual (Uji t)}

Hasil pengujian model regresi tanpa moderasi menunjukkan bahwa variabel nilai 
laba per saham (EPS), nilai buku ekuitas per lembar saham (BVPS), nilai hutang dibagi total ekuitas (DER), dan nilai arus kas operasi per jumlah saham beredar (OCFS) terbukti memiliki relevansi nilai dimana keempatnya memiliki koefisien positif dan nilai signifikansi di bawah tingkat kepercayaan 5\%, sebagaimana ditunjukkan dalam Lampiran 2. Sedangkan untuk hasil interaksi pemoderasi konservatisme akuntansi pada model regresi dengan moderasi, hanya 1 variabel yang memiliki signifikansi di bawah tingkat kepercayaan 0,05 yaitu 0,021 untuk Cit_OCFS dengan koefisien bertanda negatif. Hal ini menunjukkan bahwa konservatisme akuntansi secara signifikan memperlemah relevansi nilai arus kas operasi terhadap harga saham.

\section{Uji Koefisien Determinasi Disesuaikan (Adjusted R ${ }^{2}$ )}

Hasil pengujian Adjusted $R^{2}$ dalam Lampiran 2, menunjukkan bahwa untuk pengujian model regresi tanpa moderasi, $45,9 \%$ variasi harga saham dapat dijelaskan oleh variabel EPS, BVPS, DER, dan OCFS. Sedangkan untuk pengujian model regresi dengan moderasi, 51,2\% dari variasi harga saham dapat dijelaskan oleh variabel EPS, BVPS, DER, OCFS, Cit_EPS, Cit_BVPS, Cit_DER, dan Cit_OCFS

Tabel 1

Ikhtisar Analisis Penelitian

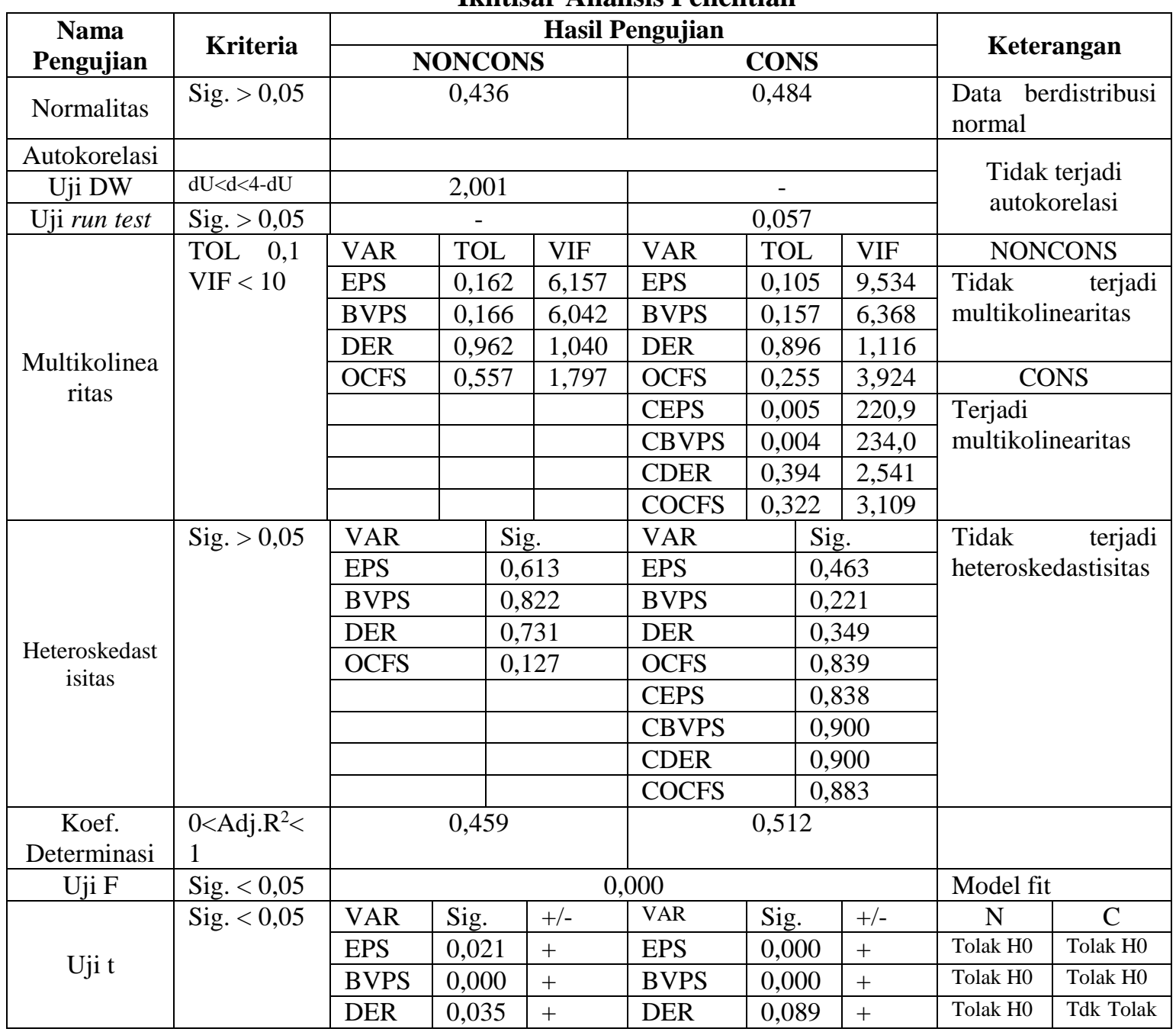




\begin{tabular}{|c|c|c|c|c|c|c|c|c|c|}
\hline \multirow{6}{*}{ 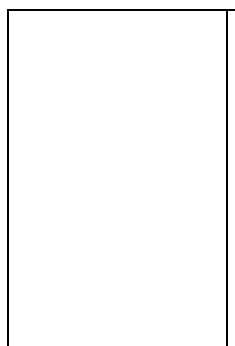 } & \multirow{6}{*}{ 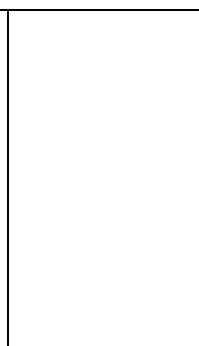 } & 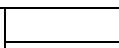 & & & & & & & $\mathrm{H} 0$ \\
\hline & & OCFS & 0,012 & + & OCFS & 0,463 & - & Tolak H0 & $\begin{array}{l}\text { Tdk Tolak } \\
\text { H0 }\end{array}$ \\
\hline & & & & & CEPS & 0,296 & - & & $\begin{array}{l}\text { Tdk Tolak } \\
\text { H0 }\end{array}$ \\
\hline & & & & & CBVPS & 0,469 & + & & $\begin{array}{l}\text { Tdk Tolak } \\
\text { H0 }\end{array}$ \\
\hline & & & & & CDER & 0,365 & + & & $\begin{array}{l}\text { Tdk Tolak } \\
\text { H0 }\end{array}$ \\
\hline & & & & & COCFS & 0,021 & - & & Tolak H0 \\
\hline
\end{tabular}

\section{Pembahasan}

\section{Relevansi Nilai Informasi Akuntansi Terhadap Harga Saham}

Berdasarkan hasil uji signifikansi t, variabel nilai laba per saham (EPS), nilai buku ekuitas per saham (BVPS), debt to equity ratio (DER), dan arus kas operasi per saham (OCFS) terbukti masih memiliki relevansi nilai terhadap harga saham dalam pengaruh yang positif dan signifikan. Nilai laba per saham merupakan suatu indikator yang sering digunakan untuk mengukur tingkat efisiensi manajemen, karena mengandung informasi yang berguna untuk memprediksi harga saham di masa mendatang. Selain itu juga merupakan cerminan dari net of capital contribution, yang menyediakan suatu informasi yang bermanfaat dalam meningkatkan nilai ekuitas perusahaan. Sehingga apabila laba aktual yang diumumkan melebihi dari laba yang diekspektasikan sebelumnya, maka hal ini akan dianggap sebagai good news sehingga hal ini akan mendorong investor untuk merevisi keyakinannya melalui aksi pembelian saham pada perusahaan yang mengumumkan nilai laba per saham yang tinggi, yang selanjutnya akan menimbulkan naiknya jumlah permintaan saham dan mendorong kenaikan harga saham penutupan, hal ini sejalan dengan penelitian (Nyabundi, 2013; Omokhudu \& Ibadin, 2015).

Nilai buku ekuitas bersama-sama dengan present value of expected future income merupakan komponen pembentuk nilai pasar perusahaan (Ohlson, 1995). Nilai buku ekuitas dipandang penting bagi investor karena perannya sebagai proksi yang menggambarkan pendapatan normal masa men- datang (expected future normal earning), dan juga dipandang penting terutama saat perusahaan sedang mengalami rugi atau krisis, karena perannya sebagai nilai penolakan (Collins et al., 1999). Dengan demikian, jika suatu perusahaan memiliki nilai buku ekuitas yang baik, maka hal tersebut dapat meningkatkan keyakinan investor untuk berinvestasi, yang selanjutnya dapat meningkatkan permintaan akan saham dan berujung pada kenaikan harga saham. Hasil penelitian ini sejalan dengan penelitian (Hail, 2013; Lam et al., 2013).

Nilai leverage yang diproksikan oleh debt to equity ratio merupakan rasio yang menggambarkan kemampuan modal sendiri dalam mengantisipasi seluruh hutang, termasuk hutang lancar dan tidak lancar. Dalam suatu kontrak atau perjanjian hutang, manajer selaku pihak internal perusahaan cenderung memiliki informasi yang lebih baik mengenai prospek mendatang dari suatu proyek dibanding investor selaku pihak eksternal. Apabila manajer dapat mewujudkan kinerja baik atas proyek yang dikelola, hal ini selanjutnya akan meningkatkan kredibilitas manajer sekaligus tindakan investor untuk merevisi keyakinannya melalui aksi pembelian atau penahanan saham, yang berdampak pada kenaikan harga saham. Hasil ini sejalan dengan penelitian (Pebriana, 2014).

Informasi arus kas operasi merupakan cerminan dari kemampuan perusahaan untuk menjalankan aktivitas operasinya, melunasi pinjaman, serta yang menjadi isu krusial adalah kemampuan perusahaan membayar dividen. Berdasarkan teori biaya agensi/agency cost, tujuan perusahaan ber- 
komitmen dalam membayar dividen adalah untuk meyakinkan pemegang saham bahwa manajer tidak akan menyia-nyiakan uang mereka. Dengan jaminan ini, maka diharapkan mampu merevisi penilaian investor untuk berani menilai harga saham perusahaan secara lebih tinggi (Gitman \& Zutter, 2015). Sehingga semakin tinggi arus kas operasi yang diumumkan akan memberikan suatu sinyal yang baik di mata investor yang berdampak pada kenaikan harga saham. Hasil ini sejalan dengan penelitian (Hail, 2013; Omokhudu \& Ibadin, 2015).

\section{Pengaruh Penerapan Konservatisme Pada Relevansi Nilai Informasi Akuntansi Terhadap Harga Saham}

Berdasarkan hasil uji signifikansi t pada model regresi dengan moderasi, konservatisme hanya terbukti memperlemah relevansi nilai arus kas operasi, tetapi tidak terbukti mampu memoderasi variabel lain seperti laba per saham (Cit_EPS), nilai buku per saham (Cit_BVPS), dan debt to equity ratio (Cit_DER) dalam pengaruh yang signifikan secara statistik. Hasil penelitian ini tidak sejalan dengan (Darsono, 2012) yang berhasil membuktikan bahwa konservatisme terbukti mampu memperlemah relevansi nilai laba dan memperkuat relevansi nilai buku secara signifikan. Hal ini mungkin disebabkan oleh praktik konservatisme yang mengalami penurunan setelah adopsi IFRS (Andre \& Filip, 2012), terutama karena periode penelitian yang diambil adalah tahun 20132016, dimana IFRS telah diadopsi secara penuh sejak 1 Januari 2012 (Juanda, 2012). Hal ini mungkin disebabkan karena prinsip pengukuran nilai wajar (fair value) yang diimplementasikan sejak penerapan IFRS telah dapat mengurangi/menghilangkan masalah asimetri pengukuran antara pendapatan dan biaya, sehingga menurut manajer (agent) penerapan praktik konservatisme akuntansi dinilai tidak relevan dalam upaya mengurangi konflik/tuntutan hukum.
Hal ini berhasil dibuktikan dalam penelitian ini karena berdasarkan 320 sampel observasi yang diteliti, hanya 123 perusahaan yang terindikasi menerapkan praktik konservatisme. Hal ini menunjukkan bahwa praktik konservatisme tidak diterapkan secara berlebihan dari sampel penelitian yang diteliti, karena jumlahnya masih kurang dari setengah keseluruhan sampel yang diobservasi. Argumen ini sejalan dengan (Kousenidis et al., 2009) yang menyatakan bahwa apabila perusahaan menerapkan konservatisme dalam batas yang tidak berlebihan (sedang-sedang saja) maka informasi yang disajikan masih memiliki relevansi nilai terhadap keputusan investor, dengan kata lain masih dapat dijadikan bahan pertimbangan untuk merevisi keyakinan investor sehingga konservatisme tidak terbukti memperlemah relevansi nilai laba dan konservatisme juga tidak terbukti memperkuat relevansi nilai leverage dan nilai buku ekuitas terhadap harga saham.

Sedangkan konservatisme yang terbukti memperlemah relevansi nilai arus kas operasi terhadap harga saham mungkin disebabkan karena sejumlah investor yang masih menggunakan prinsip pengukuran berdasarkan biaya historis, yang erat kaitannya dengan masalah pengukuran karena adanya asimetri informasi atas pendapatan dan biaya. Informasi arus kas masa lalu merupakan suatu bahan pertimbangan yang penting bagi investor karena dapat mencerminkan filosofi, atau sikap terkait dengan rekam jejak perusahaan sehubungan dengan pembayaran dividennya, investasi maupun reinvestasi atas kas yang tersedia, serta kemampuan perusahaan dalam mendapatkan tambahan pendanaan (Hendriksen \& Breda, 1992). Sehingga informasi arus kas yang diukur berdasarkan biaya historis ini dinilai lebih memberikan kehandalan (reliable) (Hendriksen \& Breda, 1992), dimana hal ini sesuai dengan prinsip konservatisme yang lebih menekankan pada reliabilitas (Juanda, 2012). Hal ini mengindikasikan bahwa perusahaan yang menggunakan prinsip pengukuran biaya historis ini merupakan 
perusahaan yang konservatif. Perusahaan yang menerapkan prinsip konservatif pada dasarnya cenderung membatasi pengungkapan informasi yang relevan (Hendriksen \& Breda, 1992:149), dalam hal ini adalah informasi arus kas operasi. Hal ini sejalan dengan penemuan Karami \& Hajiazimi (2013) yang membuktikan bahwa konservatisme merupakan suatu prosedur yang menurunkan tingkat pengungkapan informasi sehingga menyebabkan penurunan relevansi nilai variabel-variabel akuntansi.

\section{Simpulan Dan Saran}

\section{Simpulan}

Berdasarkan hasil analisis dan temuan, bahwa informasi akuntansi (laba, nilai buku ekuitas, leverage, dan arus kas operasi) masih memiliki relevansi nilai terhadap harga saham. Selain itu, praktik konservatisme semakin mengalami penurunan selama periode 2013-2016 pasca adopsi IFRS. Hal ini menyebabkan praktik konservatisme hanya terbukti memperlemah relevansi nilai arus kas operasi terhadap harga saham.

\section{Saran}

Berdasarkan penelitian yang telah dilakukan, terdapat beberapa saran yang ingin peneliti sampaikan untuk penelitian berikutnya, diantaranya menggunakan variabel independen lain seperti intangible assets, $R \& D$, dividen, maupun variabel lain yang memiliki kemungkinan relevansi nilai juga, memasukkan ketiga jenis arus kas, yaitu arus kas operasi, arus kas investasi, dan arus kas pendanaan untuk memperoleh hasil yang lebih detail, membandingkan perbedaan relevansi nilai informasi akuntansi sebelum dan sesudah konvergensi IFRS, melakukan pengujian relevansi nilai berdasarkan siklus hidup perusahaan yg terdiri atas 4 tahapan, yaitu start up, growth, mature, dan decline, menggunakan variabel moderasi baru seperti Investment Opportunity Set, Restatement, Earning Management, rasio-rasio keuangan, serta variabel moderasi lainnya sehingga dapat menemukan hasil yang berbeda dan lebih terperinci.

\section{Daftar Pustaka}

Adibah, J., Nor, A. M., \& Asyaari, E. A. 2009. Corporate Governance Reform and the Value Relevance of Equity Book Value and Earnings in Malaysia. Journal of Financial Reporting \& Accounting, Vol.7, No.2, pp.41-59.

Almilia, L. S., \& Sulistyowati, D. 2007. Analisa Terhadap Relevansi Nilai Laba, Arus Kas Operasi dan Nilai Buku Ekuitas Pada Periode di Sekitar Krisis Keuangan Pada Perusahaan Manufaktur di BEJ. Proceeding Seminar Nasional, pp.1-17.

Andre, P., \& Filip, A. 2012. Accounting Conservatism in Europe and The Impact of Mandatory IFRS Adoption: Do Country, Institutional and Legal Differences Survive? Working Paper.

Balachandran, S. V., \& Mohanram, P. S. 2005. Conservatism and the Value Relevance of Accounting Information. E-Journal Columbia Business School, pp.1-41.

Barth, M. E., Beaver, W. H., \& Landsman, W. R. .2001. The Relevance of The Value Relevance Literature For Financial Accounting Standard Setting: Another View. Journal of Accounting and Economics, Vol.31, No.1-3, pp.77-104.

Black, E. L. 1998. Which is More ValueRelevant: Earnings or Cash Flows? SSRN Electronic Journal, May, pp.1-49.

Collins, D. W., Maydew, E. L., \& Weiss, I. S. .1997. Changes In The Value- 
Relevance of Earnings and Book Values Over The Past Forty Years. Journal of Accounting and Economics, Vol.24, pp.39-67.

Collins, D. W., Pincus, M., \& Xie, H. 1999. Equity Valuation and Negative Earnings: The Role of Book Value of Equity. The Accounting Review, Vol.74, No.1, pp.26-91.

Darsono. 2012. Dampak Konservatisma Terhadap Relevansi Nilai Informasi Akuntansi Di Indonesia. Disertasi. Yogyakarta: Universitas Gajah Mada.

Devi, P. L. S., \& Badjra, I. B. 2014. Pengaruh ROE, NPM, Leverage dan Nilai Pasar Terhadap Harga Saham. EJurnal Manajemen Universitas Udayana, Vol.3, No.2, pp.259-278.

Dewi, N. K. S. L., \& Suryanawa, I. K. 2014. Pengaruh Struktur Kepemilikan Manajerial, Leverage, Dan Financial Distress Terhadap Konservatisme Akuntansi. E-Jurnal Akuntansi Universitas Udayana, Vol.7, No.1, pp.223-234.

Dimitrov, V., \& Jain, P. C. 2008. The ValueRelevance of Changes in Financial Leverage Beyond Growth in Assets and GAAP Earnings. Journal of Accounting, Auditing \& Finance, Vol.23, No.2, pp.191-222.

Disatnik, D., \& Sivan, L. 2016. The multicollinearity illusion in moderated regression analysis. Marketing Letters, Vol.27, No.2, pp.403-408.

Francis, J., \& Schipper, K. 1999. Have Financial Statements Lost Their Relevance? Source Journal of Accounting Research Journal of Accounting Research, Vol.37,
No.2, pp.319-352.

Gitman, L. J., \& Zutter, C. J. 2015. Principles of Managerial Finance, Edisi 13, London: Pearson Education Limited.

Givoly, D., \& Hayn, C. 2000. The Changing Time-Series Properties of Earnings, Cash Flows and Accruals: Has Financial Reporting Become More Conservative? Journal of Accounting and Economics, Vol.29, No.3, pp.287-320.

Givoly, D., \& Hayn, C. 2002. Rising Conservatism: Implications for Financial Analysis. Financial Analysts Journal, Vol.58, No.1, pp.56-74.

Haghiri, A., \& Haghiri, S. 2012. The Investigation of Effective Factors on Stock Return with Emphasis on ROA and ROE Ratios in Tehran Stock Exchange ( TSE ). Journal of Basic and Applied Scientific Research, Vol.2, No.9, pp.90979103.

Hail, L. 2013. Financial Reporting and Firm Valuation: Relevance Lost or Relevance Regained? Accounting and Business Research, Vol.43, No.4, pp.329-358.

Hendriksen, E. S., \& Breda, M. F. Van. 1992. Accounting Theory, Edisi 5, McGraw Hill Education.

Juanda, A. 2012. Kandungan Prinsip Konservatisme Dalam Standar Akuntansi Keuangan Berbasis IFRS (International Financial Reporting Standard). Jurnal Humanity, Vol.7, No.2, pp.24-34.

Julianto, P. A. 2017. Indonesia Masuk 10 Besar Negara Industri Manufaktur. 
Kompas. Retrieved from https://ekbis.sindonews.com/read/1 192424/34/indonesia-masuk-10besar-negara-industri-manufaktur1490772241

Karami, G., \& Hajiazimi, F. 2013. Value Relevance of Conditional Conservatism and the Role of Disclosure: Empirical Evidence from Iran. International Business Research, Vol.6, No,3, pp.66-74.

Karunarathne, W. V. D. A., \& Rajapakse, R. M. D. A. P. 2010. The Value Relevance of Financial Statements' Information: With Special Reference To The Listed Companies in Colombo Stock Exchange. ICBI 2010 - University of Kelaniya, Sri Lanka, pp.1-20.

Kieso, D. E., Weygandt, J. J., \& Warfield, T. D. 2011. Intermediate Accounting, Edisi 14, USA: John Wiley \& Sons Inc.

Kieso, D. E., Weygandt, J. J., \& Warfield, T. D. 2014. Intermediate Accounting, Edisi 15, USA: John Wiley \& Sons Inc.

Kousenidis, D. V., Ladas, A. C., \& Negakis, C. I. 2009. Value relevance of conservative and non-conservative accounting information. International Journal of Accounting, Vol.44, No.3, pp.219238.

Kwon, G. J. 2009. The Value Relevance of Book Values, Earnings and Cash flows: Evidence from South Korea. International Journal of Business and Management, Vol.4, No.10, pp.28-42.

'Laba Volkswagen naik US\$3,8 miliar' 2016, Kontan, 1 Juni 2016, diakses 30
November

2017 , http://internasional.kontan.co.id/ne ws/laba-volkswagen-naik-us-38miliar

Lam, K. C. K., Sami, H., \& Zhou, H. 2013. Changes in The Value Relevance of Accounting Information Over Time: Evidence from The Emerging Market of China. Journal of Contemporary Accounting and Economics, Vol.9, No.2, pp.123135.

Luciana, A. 2017. Menperin Sebut 6 Sektor Pendongkrak Pertumbuhan Industri 2018, Tempo, diakses 22 Desember 2017 , https://bisnis.tempo.co/read/104124 7/menperin-sebut-6-sektorpendongkrak-pertumbuhanindustri-2018

Mashayekhi, B., Faraji, O., \& Tahriri, A. 2013. Accounting Disclosure, Value Relevance and Firm Life Cycle: Evidence from Iran. International Journal of Economic Behavior and Organization, Vol.1, No.6, pp.6977.

Mayangsari, S. 2004. Analisa terhadap Relevansi Nilai (Value-Relevance) Laba, Arus Kas dan Nilai Buku Ekuitas: Analisa Diseputar Perioda Krisis Keuangan 1995-1998. Simposium Nasional Akuntansi VII, pp.862-882.

Mutia, E. 2012. Pengaruh Informasi Laba dan Arus Kas Terhadap Harga Saham. Jurnal Akuntansi (Media Riset Akuntansi \& Keuangan), Vol.1, No.1, pp.12-22.

Nyabundi, M. A. 2013. Value Relevance of Financial Statements Information: Evidence from Listed Firms in Kenya. Advances in Management 
and Applied Economics, Vol.3, No.1, pp.115-134.

Ohlson, J. 1995. Earnings, Book Values, and Dividends in Equity Valuation. Contemporary Accounting Research, Vol.11, No.2, pp.661687.

Omokhudu, O. O., \& Ibadin, P. O. 2015. The Value Relevance of Accounting Information: Evidence from Nigeria. Accounting and Finance Research, Vol.4, No.3, pp.20-30.

Pebriana, F. 2014. Analisis EPS, ROA, Dan DER Terhadap Harga Saham Perusahaan-Perusahaan Yang Tergabung Dalam Indeks Sri Kehati Di Bursa Efek Indonesia (BEI) Periode 2010-2013. Jakarta:Universitas Esa Unggul.

Penman, S. H., \& Zhang, X. 2002. Accounting Conservatism, the Quality of Earnings, and Stock Returns. The Accounting Review, Vol.77, No.2, pp.237-264.

Pinasti, M. 2004. Faktor-Faktor Yang Menjelaskan Variasi RelevansiNilai Informasi Akuntansi: Pengujian Hipotesis Informasi Alternatif. Simposium Nasional Akuntansi VII. Denpasar, Bali, Desember, pp.1-16.

Pratanda, R. S., \& Kusmuriyanto. 2014. Pengaruh Mekanisme Good Corporate Governance, Likuiditas, Profitabilitas, dan Leverage Terhadap Konservatisme Akuntansi. Accounting Analysis Journal, Vol.3, No.2, pp.255-263.

Schroeder, R., W. Clark, M., \& M. Cathey, J. 2014. Financial Accounting Theory and Analysis (11th ed.). New Jersey: John Wiley \& Sons Inc.
Scott, W. R. 2015. Financial Accounting Theory, Edisi 7, USA: Pearson Canada, Inc.

Stella. 2009. Pengaruh Price to Earning Ratio, Debt to Equity Ratio, Return on Asset, dan Price to Book Value terhadap Harga Pasar Saham. Jurnal Bisnis Dan Akuntansi, Vol.11, No.2, pp.97-106.

Sugiarti, Y., \& Suyanto. 2007. Pengaruh Informasi Keuangan (Book Value Dan Earning Per Share) Terhadap Harga Saham Perusahaan Perbankan. Jurnal Akuntansi Dan Teknologi Informasi, Vol.6, November, pp.79-92.

Suwardjono. 2014. Teori Akuntansi Perekayasaan Pelaporan Keuangan. Edisi 3. BPFEYOGYAKARTA.

Viandita, T. O., Suhadak, \& Husaini, A. 2013. Pengaruh Debt Ratio (DR), Price To Earning Ratio (PER), Earning Per Share (EPS), dan Size Terhadap Harga Saham (Studi Pada Perusahaan Industri Yang Terdaftar Di Bursa Efek Indonesia). Jurnal Administrasi Bisnis (JAB), Vol.1, No.2, pp.113-121.

Watts, R. 2003. Conservatism in Accounting Part I: Explanations and Implications. Accounting Horizons, Vol.17, No.3, pp.207-221.

Watts, R. L., \& Zimmerman, J. L. 1986. Positive Accounting Theory. New Jersey: Prentice Hall, Inc.

Widiastuti, N. P. E., \& Meiden, C. 2012. Moderasi Deferred Tax Expense Atas Relevansi Nilai Laba dan Buku Ekuitas Pada Perusahaan Manufaktur Yang Terdaftar Di BEI Tahun 2008-2010. Jurnal InFestasi, 
Vol.8, No.1, pp.1-14.

Yendrawati, R., \& Pratiwi, R. S. I. 2014. Relevansi Nilai Informasi Laba dan Arus Kas Terhadap Harga Saham. Jurnal Dinamika Manajemen, Vol.5, No.2, pp.161-170.
Zakic, V., Vasiljevic, Z., \& Zaric, V. 2012. Relevance of Dividend Policy for Food Industry Corporations in Serbia. Review Article of Rconomic and Agriculture, Vol.4, No.59, pp.809-823.

\section{LAMPIRAN}

\section{Lampiran 1}

Daftar Perusahaan Sampel

\begin{tabular}{cccc}
\hline No. & KODE & \multicolumn{1}{c}{ Nama Perusahaan } & Tanggal Listing \\
\hline 1 & ADES & PT. Akasha Wira International Tbk d.h.Ades Waters Indonesia Tbk & 13-Jun-94 \\
2 & AKPI & PT. Argha Karya Prima Industri Tbk & 18-Des-1992 \\
3 & ALDO & PT. Alkindo Naratama Tbk & 12-Jul-11 \\
4 & ALKA & PT. Alaska Industrindo Tbk & 12-Jul-90 \\
5 & ALMI & PT. Alumindo Industrindo Tbk & 02-Jan-97 \\
6 & ALTO & PT. Tri Banyan Tirta Tbk & 10-Jul-12 \\
7 & AMFG & PT. Asahimas Flat Glass Tbk & 08-Nov-95 \\
8 & APLI & PT. Asiaplast Industries Tbk & 01-Mei-2000 \\
9 & ARNA & PT. Arwana Citra Mulia Tbk & 17-Jul-01 \\
10 & AUTO & PT. Astra Auto Part Tbk & 15-Jun-98 \\
11 & BAJA & PT. Saranacentral Bajatama Tbk & 21-Dec-11 \\
12 & BIMA & PT. Primarindo Asia Infrastructure Tbk d.h.Bintang Kharisma & 30-Agt-1994 \\
13 & BRNA & PT. Berlina Tbk & 06-Nov-89 \\
14 & BTON & PT. Beton Jaya Manunggal Tbk & 18-Jul-01 \\
15 & BUDI & PT. Budi Starch and Sweetener Tbk d.h Budi Acid Jaya Tbk & 08-Mei-1995 \\
16 & CEKA & PT. Wilmar Cahaya Indonesia Tbk d.h. Cahaya Kalbar Tbk & 09-Jul-96 \\
17 & CPIN & PT. Charoen Pokphand Indonesia Tbk & 18-Mar-91 \\
18 & DPNS & PT. Duta Pertiwi Nusantara Tbk & 08-Agt-1990 \\
19 & DVLA & PT. Darya Varia Laboratoria Tbk & 11-Nov-94 \\
20 & EKAD & PT. Ekadharma International Tbk & 14-Agt-1990 \\
21 & FASW & PT. Fajar Surya Wisesa Tbk & 01-Des-1994 \\
22 & GDST & PT. Gunawan Dianjaya Steel Tbk & 23-Des-2009 \\
23 & GGRM & PT. Gudang Garam Tbk & 27-Agt-1990 \\
24 & GJTL & PT. Gajah Tunggal Tbk & 08-Mei-1990 \\
25 & HDTX & PT. Panasia Indo Resources Tbk d.h. Panasia Indosyntec Tbk & 06-Jun-90 \\
26 & ICBP & PT. Indofood CBP Sukses Makmur Tbk & 07-Okt-2010 \\
27 & IGAR & PT. Champion Pasific Indonesia Tbk d.h.Kageo Igar Jaya Tbk & 05-Nov-90 \\
28 & IKAI & PT. Inti Keramik Alam Asri Industri Tbk & 04-Jun-97
\end{tabular}




\begin{tabular}{|c|c|c|c|}
\hline 29 & IMAS & PT. Indomobil Sukses International Tbk & 15-Nov-93 \\
\hline 30 & INAF & PT. Indofarma Tbk & 17-Apr-01 \\
\hline 31 & INAI & PT. Indal Aluminium Industry Tbk & 05-Des-1994 \\
\hline 32 & INCI & PT. Intan Wijaya International Tbk & 24-Jul-90 \\
\hline 33 & INDF & PT. Indofood Sukses Makmur Tbk & 14-Jul-94 \\
\hline 34 & INDS & PT. Indospring Tbk & 10-Agt-1990 \\
\hline 35 & INTP & PT. Indocement Tunggal Perkasa Tbk & 05-Des-1989 \\
\hline 36 & JECC & PT. Jembo Cable Company Tbk & 18-Nov-92 \\
\hline 37 & JKSW & PT. Jakarta Kyoei Steel Work LTD Tbk & 06-Agt-1997 \\
\hline 38 & JPFA & PT. Japfa Comfeed Indonesia Tbk & 23-Okt-1989 \\
\hline 39 & JPRS & PT. Jaya Pari Steel Tbk & 08-Agt-1989 \\
\hline 40 & KAEF & PT. Kimia Farma Tbk & 04-Jul-01 \\
\hline 41 & KBLI & PT. KMI Wire and Cable Tbk & 06-Jul-92 \\
\hline 42 & KBLM & PT. Kabelindo Murni Tbk & 01-Jun-92 \\
\hline 43 & KBRI & PT. Kertas Basuki Rachmat Indonesia Tbk & 11-Jul-08 \\
\hline 44 & $\mathrm{KICI}$ & PT. Kedaung Indah Can Tbk & 28-Okt-1993 \\
\hline 45 & KLBF & PT. Kalbe Farma Tbk & 30-Jul-91 \\
\hline 46 & LION & PT. Lion Metal Works Tbk & 20-Agt-1993 \\
\hline 47 & LMPI & PT. Langgeng Makmur Industri Tbk & 17-Okt-1994 \\
\hline 48 & MAIN & PT. Malindo Feedmill Tbk & $10-F e b-06$ \\
\hline 49 & MBTO & PT. Martina Berto Tbk & 13-Jan-11 \\
\hline 50 & MLIA & PT. Mulia Industrindo Tbk & 17-Jan-94 \\
\hline 51 & MRAT & PT. Mustika Ratu Tbk & 27-Jul-95 \\
\hline 52 & MYOR & PT. Mayora Indah Tbk & 04-Jul-90 \\
\hline 53 & MYTX & PT. Apac Citra Centertex Tbk & 10-Okt-1989 \\
\hline 54 & NIPS & PT. Nippres Tbk & 24-Jul-91 \\
\hline 55 & PRAS & PT. Prima Alloy Steel Universal Tbk & 12-Jul-90 \\
\hline 56 & PYFA & PT. Pyridam Farma Tbk & 16-Okt-2001 \\
\hline 57 & RICY & PT. Ricky Putra Globasindo Tbk & 22-Jan-98 \\
\hline 58 & ROTI & PT. Nippon Indosari Corporindo Tbk & 28-Jun-10 \\
\hline 59 & SCCO & PT. Supreme Cable Manufacturing and Commerce Tbk & 20-Jul-82 \\
\hline 60 & SKBM & PT. Sekar Bumi Tbk & 28-Sep-12 \\
\hline 61 & SKLT & PT. Sekar Laut Tbk & 08-Sep-93 \\
\hline 62 & SMCB & PT. Holcim Indonesia Tbk & 10-Agt-1977 \\
\hline 63 & SMGR & PT. Semen Indonesia d/h Semen Gresik Tbk & 08-Jul-91 \\
\hline 64 & SMSM & PT. Selamat Sempurna Tbk & 09-Sep-96 \\
\hline 65 & SPMA & PT. Suparma Tbk & 15-Nov-94 \\
\hline 66 & SRSN & PT. Indo Acitama Tbk & 11-Jan-93 \\
\hline 67 & SSTM & PT. Sunson Textile Manufacturer Tbk & 20-Agt-1997 \\
\hline
\end{tabular}




\begin{tabular}{cclc}
68 & STAR & PT. Star Petrochem Tbk & 13-Jul-11 \\
69 & STTP & PT. Siantar Top Tbk & 16-Des-1996 \\
70 & TALF & PT. Tunas Alfin Tbk & 17-Jan-12 \\
71 & TCID & PT. Mandom Indonesia Tbk & 23-Sep-93 \\
72 & TOTO & PT. Surya Toto Indonesia Tbk & 30-Okt-1990 \\
73 & TRIS & PT. Trisula International Tbk & 28-Jun-12 \\
74 & TRST & PT. Trias Sentosa Tbk & 02-Jul-90 \\
75 & TSPC & PT. Tempo Scan Pasifik Tbk & 17-Jun-94 \\
76 & ULTJ & PT. Ultrajaya Milk Industry and Trading Company Tbk & 02-Jul-90 \\
77 & UNIT & PT. Nusantara Inti Corpora Tbk & 18-Apr-02 \\
78 & VOKS & PT. Voksel Electric Tbk & 20-Des-1990 \\
79 & WIIM & PT. Wismilak Inti Makmur Tbk & 18-Des-2012 \\
80 & YPAS & PT. Yana Prima Hasta Persada Tbk & 05-Mar-08 \\
\hline
\end{tabular}

\section{Lampiran 2}

\section{Hasil Pengujian Model Regresi Tanpa Moderasi}

\section{Hasil Uji Fixed Effect}

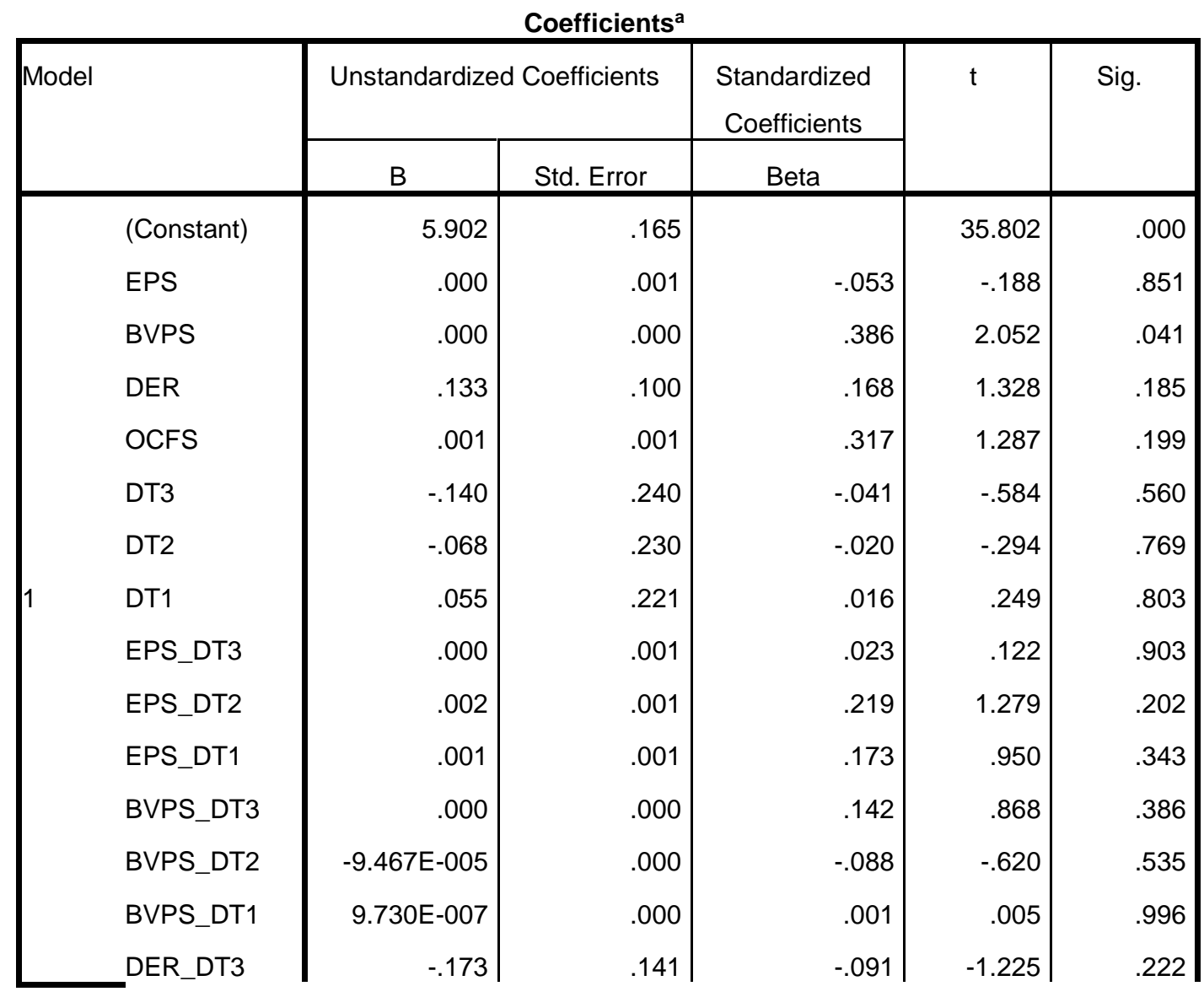




\begin{tabular}{|l|r|r|r|r|r|}
\hline DER_DT2 & -.035 & .123 & -.023 & -.281 & .779 \\
DER_DT1 & -.084 & .110 & -.082 & -.766 & .444 \\
OCFS_DT3 & -.001 & .001 & -.140 & -.945 & .345 \\
OCFS_DT2 & .000 & .001 & -.020 & -.167 & .868 \\
OCFS_DT1 & -.001 & .001 & -.121 & -.893 & .373 \\
\hline
\end{tabular}

a. Dependent Variable: LnCP

\section{Hasil Uji Normalitas}

\begin{tabular}{|ll|r|}
\hline \multicolumn{2}{|c|}{ One-Sample Kolmogorov-Smirnov Test } \\
\hline $\mathrm{N}$ & $\begin{array}{c}\text { Unstandardized } \\
\text { Residual }\end{array}$ \\
Normal Parameters ${ }^{\mathrm{a}, \mathrm{b}}$ & Mean & 319 \\
& Std. Deviation & $0 \mathrm{E}-7$ \\
& Absolute & 1.06739851 \\
Most Extreme Differences & Positive & .049 \\
& Negative & .045 \\
Kolmogorov-Smirnov Z & & -.049 \\
Asymp. Sig. (2-tailed) & & .870 \\
\hline
\end{tabular}

a. Test distribution is Normal.

b. Calculated from data.

\section{Hasil Uji Multikolinearitas}

\begin{tabular}{|c|c|c|c|c|c|c|c|c|}
\hline \multicolumn{9}{|c|}{ Coefficients $^{a}$} \\
\hline \multirow{2}{*}{\multicolumn{2}{|c|}{ Model }} & \multicolumn{2}{|c|}{$\begin{array}{c}\text { Unstandardized } \\
\text { Coefficients }\end{array}$} & \multirow{2}{*}{$\begin{array}{c}\text { Standardized } \\
\text { Coefficients } \\
\text { Beta }\end{array}$} & \multirow[t]{2}{*}{$\mathrm{t}$} & \multirow[t]{2}{*}{ Sig. } & \multicolumn{2}{|c|}{ Collinearity Statistics } \\
\hline & & $\mathrm{B}$ & Std. Error & & & & Tolerance & VIF \\
\hline \multirow{5}{*}{1} & (Constant) & 4.654 & .069 & & 67.633 & .000 & & \\
\hline & LAG_EPS & .001 & .000 & .205 & 2.000 & .046 & .162 & 6.157 \\
\hline & LAG_BVPS & .000 & .000 & .396 & 3.906 & .000 & .166 & 6.042 \\
\hline & LAG_DER & .056 & .031 & .076 & 1.810 & .071 & .962 & 1.040 \\
\hline & LAG_OCFS & .000 & .000 & .126 & 2.276 & .024 & .557 & 1.797 \\
\hline
\end{tabular}

a. Dependent Variable: LAG_LnCP 


\section{Hasil Uji Autokorelasi}

Model Summaryb

\begin{tabular}{|l|r|r|r|r|r|}
\hline Model & \multicolumn{1}{|c|}{$\mathrm{R}$} & R Square & $\begin{array}{c}\text { Adjusted R } \\
\text { Square }\end{array}$ & $\begin{array}{c}\text { Std. Error of the } \\
\text { Estimate }\end{array}$ & Durbin-Watson \\
\hline 1 & $.683^{\mathrm{a}}$ & .466 & .459 & 1.07417571235 & 2.001 \\
\hline
\end{tabular}

a. Predictors: (Constant), LAG_OCFS, LAG_DER, LAG_BVPS, LAG_EPS

b. Dependent Variable: LAG_LnCP

\section{Hasil Uji Heteroskedastisitas}

\begin{tabular}{|c|c|c|c|c|c|c|}
\hline \multicolumn{7}{|c|}{ Coefficients $^{a}$} \\
\hline \multirow{2}{*}{\multicolumn{2}{|c|}{ Model }} & \multicolumn{2}{|c|}{ Unstandardized Coefficients } & \multirow{2}{*}{$\begin{array}{c}\text { Standardized } \\
\text { Coefficients } \\
\text { Beta }\end{array}$} & \multirow[t]{2}{*}{$\mathrm{t}$} & \multirow[t]{2}{*}{ Sig. } \\
\hline & & $\mathrm{B}$ & Std. Error & & & \\
\hline \multirow{5}{*}{1} & (Constant) & -1.101 & .145 & & -7.598 & .000 \\
\hline & LAG_EPS & .000 & .001 & .070 & .507 & .613 \\
\hline & LAG_BVPS & $-2.642 \mathrm{E}-005$ & .000 & -.031 & -.226 & .822 \\
\hline & LAG_DER & -.022 & .065 & -.020 & -.344 & .731 \\
\hline & LAG_OCFS & .001 & .000 & .114 & 1.529 & .127 \\
\hline
\end{tabular}

a. Dependent Variable: Ln_RES2KUADRAT

\section{Hasil Uji Koefisien Determinasi}

Model Summaryb

\begin{tabular}{|l|r|r|r|l|}
\hline Model & $\mathrm{R}$ & R Square & \multicolumn{1}{|c|}{$\begin{array}{c}\text { Adjusted R } \\
\text { Square }\end{array}$} & $\begin{array}{l}\text { Std. Error of the } \\
\text { Estimate }\end{array}$ \\
\hline 1 & $.683^{\mathrm{a}}$ & .466 & .459 & 1.07417571235 \\
\hline
\end{tabular}

a. Predictors: (Constant), LAG_OCFS, LAG_DER, LAG_BVPS,

LAG_EPS

b. Dependent Variable: LAG_LnCP 


\section{Hasil Uji Statistik F}

\begin{tabular}{|c|c|c|c|c|c|c|}
\hline \multicolumn{7}{|c|}{ ANOVA $^{a}$} \\
\hline & & Sum of Squares & df & Mean Square & $\mathrm{F}$ & Sig. \\
\hline \multirow{3}{*}{1} & Regression & 316.264 & 4 & 79.066 & 68.524 & $.000^{\mathrm{b}}$ \\
\hline & Residual & 362.310 & 314 & 1.154 & & \\
\hline & Total & 678.574 & 318 & & & \\
\hline
\end{tabular}

a. Dependent Variable: LAG_LnCP

b. Predictors: (Constant), LAG_OCFS, LAG_DER, LAG_BVPS, LAG_EPS

\section{Hasil Uji Signifikansi t}

\begin{tabular}{|r|r|r|r|r|r|}
\hline \multicolumn{2}{|c|}{ Coefficients $^{\mathrm{a}}$} \\
& \multicolumn{2}{|c|}{ Unstandardized Coefficients } & $\begin{array}{c}\text { Standardized } \\
\text { Coefficients }\end{array}$ & $\mathrm{t}$ & \multirow{2}{*}{ Sig. } \\
\cline { 2 - 6 } & $\mathrm{B}$ & Std. Error & Beta & & \\
\hline (Constant) & 4.654 & .069 & .205 & 2.000 & .046 \\
LAG_EPS & .001 & .000 & .396 & 3.906 & .000 \\
LAG_BVPS & .000 & .000 & .076 & 1.810 & .071 \\
LAG_DER & .056 & .031 & .126 & 2.276 & .024 \\
\hline
\end{tabular}

a. Dependent Variable: LAG_LnCP 
Lampiran 3

Hasil Pengujian Model Regresi Dengan Moderasi

\section{Hasil Uji Fixed Effect}

\begin{tabular}{|c|c|c|c|c|c|c|}
\hline \multicolumn{7}{|c|}{ Coefficients $^{\mathrm{a}}$} \\
\hline \multirow[t]{2}{*}{ Mod } & & \multicolumn{2}{|c|}{ Unstandardized Coefficients } & \multirow{2}{*}{$\begin{array}{c}\text { Standardized } \\
\text { Coefficients }\end{array}$} & \multirow[t]{2}{*}{$\mathrm{t}$} & \multirow[t]{2}{*}{ Sig. } \\
\hline & & $\mathrm{B}$ & Std. Error & & & \\
\hline \multirow{27}{*}{1} & (Constant) & 5.822 & .162 & & 35.886 & .000 \\
\hline & EPS & .003 & .001 & .761 & 1.929 & .055 \\
\hline & BVPS & .000 & .000 & .616 & 2.976 & .003 \\
\hline & DER & .070 & .104 & .088 & .676 & .500 \\
\hline & OCFS & -.001 & .001 & -.322 & -.975 & .331 \\
\hline & Cit_EPS & $-2.090 \mathrm{E}-015$ & .000 & -1.887 & -.493 & .623 \\
\hline & Cit_BVPS & $5.185 \mathrm{E}-016$ & .000 & 2.857 & .849 & .396 \\
\hline & Cit_DER & $2.380 \mathrm{E}-013$ & .000 & .141 & .575 & .566 \\
\hline & Cit_OCFS & $-2.163 \mathrm{E}-015$ & .000 & -1.167 & -1.218 & .224 \\
\hline & DT3 & -.235 & .234 & -.068 & -1.007 & .315 \\
\hline & DT2 & -.120 & .225 & -.035 & -.534 & .594 \\
\hline & $\mathrm{DT} 1$ & .125 & .219 & .036 & .570 & .569 \\
\hline & EPS_DT3 & -.001 & .002 & -.201 & -.794 & .428 \\
\hline & EPS_DT2 & .000 & .002 & .038 & .165 & .869 \\
\hline & EPS_DT1 & -.002 & .002 & -.258 & -1.052 & .293 \\
\hline & BVPS_DT3 & $-7.725 \mathrm{E}-005$ & .000 & -.077 & -.454 & .650 \\
\hline & BVPS_DT2 & .000 & .000 & -.166 & -1.040 & .299 \\
\hline & BVPS_DT1 & .000 & .000 & -.101 & -.565 & .573 \\
\hline & DER_DT3 & -.044 & .145 & -.023 & -.307 & .759 \\
\hline & DER_DT2 & .029 & .125 & .019 & .231 & .817 \\
\hline & DER_DT1 & -.086 & .119 & -.084 & -.721 & .472 \\
\hline & OCFS_DT3 & .002 & .001 & .368 & 1.677 & .095 \\
\hline & OCFS_DT2 & .001 & .001 & .161 & .902 & .368 \\
\hline & OCFS_DT1 & .001 & .001 & .236 & 1.307 & .192 \\
\hline & Cit_EPS_DT3 & $-3.067 \mathrm{E}-016$ & .000 & -.192 & -.068 & .945 \\
\hline & Cit_EPS_DT2 & $1.229 \mathrm{E}-015$ & .000 & .683 & .269 & .788 \\
\hline & Cit_EPS_DT1 & $5.482 \mathrm{E}-015$ & .000 & 1.410 & 1.161 & .247 \\
\hline
\end{tabular}




\begin{tabular}{|l|r|r|r|r|r|}
\hline Cit_BVPS_DT3 & $-2.365 \mathrm{E}-016$ & .000 & -.876 & -.360 & .719 \\
Cit_BVPS_DT2 & $-4.371 \mathrm{E}-016$ & .000 & -1.494 & -.649 & .517 \\
Cit_BVPS_DT1 & $-1.023 \mathrm{E}-015$ & .000 & -1.819 & -1.491 & .137 \\
Cit_DER_DT3 & $-4.902 \mathrm{E}-013$ & .000 & -.123 & -.774 & .440 \\
Cit_DER_DT2 & $-3.711 \mathrm{E}-013$ & .000 & -.108 & -.748 & .455 \\
Cit_DER_DT1 & $1.114 \mathrm{E}-013$ & .000 & .048 & .232 & .817 \\
Cit_OCFS_DT3 & $2.968 \mathrm{E}-015$ & .000 & 1.106 & 1.574 & .117 \\
Cit_OCFS_DT2 & $2.004 \mathrm{E}-015$ & .000 & .425 & 1.096 & .274 \\
Cit_OCFS_DT1 & $1.810 \mathrm{E}-015$ & .000 & .369 & .989 & .324 \\
\hline
\end{tabular}

a. Dependent Variable: LnCP

\section{Hasil Uji Normalitas}

\begin{tabular}{|ll|r|}
\hline \multicolumn{2}{|c|}{ One-Sample Kolmogorov-Smirnov Test } \\
\hline $\mathrm{N}$ & $\begin{array}{c}\text { Unstandardized } \\
\text { Residual }\end{array}$ \\
Normal Parameters ${ }^{\mathrm{a}, \mathrm{b}}$ & Mean & 320 \\
& Std. Deviation & $0 \mathrm{E}-7$ \\
& Absolute & 1.03511501 \\
Most Extreme Differences & Positive & .047 \\
& Negative & .047 \\
Kolmogorov-Smirnov Z & & -.044 \\
Asymp. Sig. (2-tailed) & & .838 \\
\end{tabular}

a. Test distribution is Normal.

b. Calculated from data.

\section{Hasil Uji Multikolinearitas}

\begin{tabular}{|c|c|c|c|c|c|c|c|c|}
\hline \multicolumn{9}{|c|}{ Coefficients $^{a}$} \\
\hline \multirow{2}{*}{\multicolumn{2}{|c|}{ Model }} & \multicolumn{2}{|c|}{$\begin{array}{c}\text { Unstandardized } \\
\text { Coefficients }\end{array}$} & \multirow{2}{*}{$\begin{array}{c}\text { Standardized } \\
\text { Coefficients } \\
\text { Beta }\end{array}$} & \multirow[t]{2}{*}{$\mathrm{t}$} & \multirow[t]{2}{*}{ Sig. } & \multicolumn{2}{|c|}{ Collinearity Statistics } \\
\hline & & $\mathrm{B}$ & Std. Error & & & & Tolerance & VIF \\
\hline \multirow{4}{*}{1} & (Constant) & 5.807 & .075 & & 77.671 & .000 & & \\
\hline & EPS & .002 & .000 & .540 & 4.471 & .000 & .105 & 9.534 \\
\hline & BVPS & .000 & .000 & .446 & 4.518 & .000 & .157 & 6.368 \\
\hline & DER & .044 & .033 & .056 & 1.353 & .177 & .896 & 1.116 \\
\hline
\end{tabular}




\begin{tabular}{|l|r|r|r|r|r|r|r|}
\hline OCFS & $-2.251 \mathrm{E}-005$ & .000 & -.007 & -.095 & .925 & .255 & 3.924 \\
Cit_EPS & $-3.460 \mathrm{E}-016$ & .000 & -.312 & -.537 & .591 & .005 & 220.902 \\
Cit_BVPS & $8.600 \mathrm{E}-018$ & .000 & .047 & .079 & .937 & .004 & 234.053 \\
Cit_DER & $3.644 \mathrm{E}-014$ & .000 & .022 & .345 & .730 & .394 & 2.541 \\
Cit_OCFS & $-2.606 \mathrm{E}-016$ & .000 & -.141 & -2.038 & .042 & .322 & 3.109 \\
\hline
\end{tabular}

a. Dependent Variable: LnCP

\section{Hasil Uji Autokorelasi}

Runs Test

\begin{tabular}{|l|r|}
\hline & $\begin{array}{c}\text { Unstandardized } \\
\text { Residual }\end{array}$ \\
\hline Test Value & .07579 \\
Cases < Test Value & 160 \\
Cases > Test Value & 160 \\
Total Cases & 320 \\
Number of Runs & 144 \\
Z & -1.904 \\
Asymp. Sig. (2-tailed) & .057 \\
\hline
\end{tabular}

\section{Hasil Uji Heteroskedastisitas}

a. Median

\begin{tabular}{|c|c|c|c|c|c|c|}
\hline \multicolumn{7}{|c|}{ Coefficients $^{a}$} \\
\hline \multirow{2}{*}{\multicolumn{2}{|c|}{ Model }} & \multicolumn{2}{|c|}{ Unstandardized Coefficients } & \multirow{2}{*}{$\begin{array}{c}\begin{array}{c}\text { Standardized } \\
\text { Coefficients }\end{array} \\
\text { Beta } \\
\end{array}$} & \multirow[t]{2}{*}{$\mathrm{t}$} & \multirow[t]{2}{*}{ Sig. } \\
\hline & & $\mathrm{B}$ & Std. Error & & & \\
\hline \multirow{9}{*}{1} & (Constant) & -.962 & .151 & & -6.379 & .000 \\
\hline & EPS & .001 & .001 & .128 & .735 & .463 \\
\hline & BVPS & .000 & .000 & -.175 & -1.227 & .221 \\
\hline & DER & .062 & .066 & .056 & .938 & .349 \\
\hline & OCFS & $-9.752 E-005$ & .000 & -.023 & -.203 & .839 \\
\hline & Cit_EPS & $2.658 \mathrm{E}-016$ & .000 & .172 & .205 & .838 \\
\hline & Cit_BVPS & $-2.761 \mathrm{E}-017$ & .000 & -.109 & -.126 & .900 \\
\hline & Cit_DER & $2.681 \mathrm{E}-014$ & .000 & .011 & .126 & .900 \\
\hline & Cit_OCFS & $-3.809 E-017$ & .000 & -.015 & -.148 & .883 \\
\hline
\end{tabular}

a. Dependent Variable: LN_RES1KUADRAT 


\section{Hasil Uji Koefisien Determinasi Disesuaikan}

\begin{tabular}{|l|r|r|r|c|}
\hline \multicolumn{7}{|c|}{ Model Summary } \\
\hline 1 & $\mathrm{R}$ & R Square & $\begin{array}{c}\text { Adjusted R } \\
\text { Square }\end{array}$ & $\begin{array}{c}\text { Std. Error of the } \\
\text { Estimate }\end{array}$ \\
\hline & $.724^{\mathrm{a}}$ & .524 & .512 & 1.0483439 \\
\hline
\end{tabular}

a. Predictors: (Constant), Cit_OCFS, DER, OCFS, Cit_DER, Cit_EPS,

BVPS, EPS, Cit_BVPS

b. Dependent Variable: LnCP

\section{Hasil Uji Statistik F}

ANOVA

\begin{tabular}{|c|c|c|c|c|c|c|}
\hline \multicolumn{2}{|c|}{ Model } & Sum of Squares & $d f$ & Mean Square & $\mathrm{F}$ & Sig. \\
\hline \multirow{3}{*}{1} & Regression & 376.647 & 8 & 47.081 & 42.839 & $.000^{\mathrm{b}}$ \\
\hline & Residual & 341.797 & 311 & 1.099 & & \\
\hline & Total & 718.443 & 319 & & & \\
\hline
\end{tabular}

a. Dependent Variable: LnCP

b. Predictors: (Constant), Cit_OCFS, DER, OCFS, Cit_DER, Cit_EPS, BVPS, EPS, Cit_BVPS

\section{Hasil Uji Signifikansi t}

\begin{tabular}{|c|c|c|c|c|c|c|}
\hline \multicolumn{7}{|c|}{ Coefficients $^{a}$} \\
\hline \multirow{2}{*}{\multicolumn{2}{|c|}{ Model }} & \multicolumn{2}{|c|}{ Unstandardized Coefficients } & \multirow{2}{*}{$\begin{array}{c}\text { Standardized } \\
\text { Coefficients } \\
\text { Beta }\end{array}$} & \multirow[t]{2}{*}{$\mathrm{t}$} & \multirow[t]{2}{*}{ Sig. } \\
\hline & & $\mathrm{B}$ & Std. Error & & & \\
\hline \multirow{9}{*}{1} & (Constant) & 5.807 & .075 & & 77.671 & .000 \\
\hline & EPS & .002 & .000 & .540 & 4.471 & .000 \\
\hline & BVPS & .000 & .000 & .446 & 4.518 & .000 \\
\hline & DER & .044 & .033 & .056 & 1.353 & .177 \\
\hline & OCFS & $-2.251 \mathrm{E}-005$ & .000 & -.007 & -.095 & .925 \\
\hline & Cit_EPS & $-3.460 \mathrm{E}-016$ & .000 & -.312 & -.537 & .591 \\
\hline & Cit_BVPS & 8.600E-018 & .000 & .047 & .079 & .937 \\
\hline & Cit_DER & 3.644E-014 & .000 & .022 & .345 & .730 \\
\hline & Cit_OCFS & $-2.606 \mathrm{E}-016$ & .000 & -.141 & -2.038 & .042 \\
\hline
\end{tabular}

a. Dependent Variable: LnCP 